\title{
Anmeldelse: Spionagens univers
}

Af Mette Skak

I det herlige digt 'Honningfælder. Hyldest til spionromanens tristesse' skildrer Søren Ulrik Thomsen koldkrigens fiktion som et fristed "hvor man ikke skal kede sig med vira og nanoteknologi og hackere og industrispionage og Al-Qaedaterrorister". Her lærte han om honningfælder og et underspillet univers med "en leverplettet morlille $i$ et anonymt engelsk rækkehus" her sigter han til Stalins mesterspion Melita Norwood.

Peter C. Oleson (red.): AFIO's Guide to the Study of Intelligence, Falls Church, VA: Association of Former Intelligence Officials, 2016. (Gratis onlineversion på https:// www.afio.com/40_guide.htm).

Her i 2018, hvor den måbende offentlighed er blevet konfronteret med Novichokattentatet på Skripal og hans datter, den ukrainske efterretningstjenestes fingerede mord på journalisten Babtjenko plus et iransk cyberangreb på danske og internationale tekniske universiteter, er det nok de færreste, der finder nutiden triviel, hvad skæg og blå briller angår.

Tværtimod har det 21. århundredes storpolitiske virkelighed for alvor rettet søgelyset mod de hemmelige tjenester og deres metoder - dels via Snowdenlækagen, dels via GRUs (den russiske militære efterretningstjeneste) hybridkrig i Ukraine og den russiske

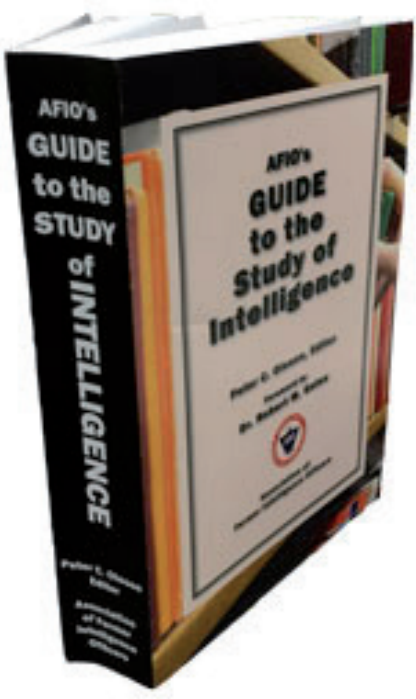
gange besøgt Rusland som led i sin forskning og er forfatter til utallige artikler og flere bøger. 
indblanding i adskillige vestlige valghandlinger, misinformation mv. Hertil kommer den langvarige kinesiske industrispionage mod USA som baggrund for Trump-administrationens tilflugt til handelskrig.

\section{Spionage og forskning}

Derfor er det yderst kærkomment med den systematiske indføring i spionagens univers, som jeg her skal anmelde. Som underviser i faget international politik på universitetsniveau har det nemlig længe undret mig, hvor tavse fagets koryfæer er om spionage som statslig praksis og dermed som empirisk belæg for sikkerhedsdilemmaet mellem staterne.

Spionagen, dens organisering og til tider afgørende indflydelse på udfald - fx under landgangen i Normandiet og Cubakrisen - forbliver uomtalt hos Kenneth N. Waltz, Joseph S. Nye og Alexander Wendt. Kun den engelske skole har blik for spionagen som fundamental institution i international politik.

Det barokke er som antydet, at spionagen om noget belyser nulsumslogikken mellem stater, idet kontraspionagen - forsvaret mod fjendtlig spionage fra omverdenens side - har vist sig lige så uomgængelig som spionagen selv; den omtales netop som verdens næstældste erhverv.

Spionagens organisering i det såkaldte efterretningskredsløb berettiger omvendt den liberale kildekritiske tilgang til staten som rationel sikkerhedspolitisk beslutningstager. I og med at autoritære politiske systemer har det med at kamme over i en patolo- gisk konspirativ spionagestrategisk kultur, rummer feltet tillige guf for konstruktivister.

Forvaltningsnørder, der ynder at svælge i modsætninger mellem agent og principal, kan kaste sig over alverdens dobbeltagenter såsom Kim Philby med hans multiple principaler. Så hvornår vågner politologerne mon $\mathrm{op}$ ?

Måske Oleson og hans perlerække af sagkyndige medforfattere - heriblandt Mark M. Lowenthal - kan rette lidt op på miseren, for det skal understreges, at bogen udgør en 'forskningsoversigt for undervisere'.

Men den interesserede engelskkyndige læser bør bestemt læse med og endnu mere den journalist, der gerne vil kunne begå sig på dette notorisk myte- og sensationsbefængte felt; lige så den student, der mangler ideer til et speciale med gods i. Bogen består nemlig af hele 72 brødkapitler skrevet af folk med lang praktisk erfaring fra deres tid i USA's utallige specialiserede efterretningstjenester, ofte topfolk.

På den måde er der unægtelig en bias til fordel for USA, men vigtigst af alt står bogen for en professionel tilgang og afliver mange myter - vel at mærke uden at være kedelig at læse. Okay, der er kapitler, der kalder på gabet hos andre end den indviede, men alle skriver godt. Bogen er forsynet med nyttige oversigter, tabeller og tankevækkende fotos, ligesom de løbende indledninger giver overblik over de enkelte brødkapitler i bogens syv dele:

- Part I: Introduction to the

Topic [:intelligence dvs. efterretningsvirksomhed]

- Part II: History of Intelligence 
- Part III: Intelligence Disciplines, Applications, and Missions

- Part IV: Espionage, Counterintelligence and Covert Action

- Part V: Policy, Oversight, and Issues

- Part VI: Intelligence Abroad

- Part VII: Miscellany

\section{Spionagens formål}

Bogens første del fastslår, at formålet med at bedrive spionage (dvs. at søge oplysninger ad hemmelige kanaler og dermed på ulovlig vis) eller søge efterretninger i bredere forstand er at opnå beslutningsfordele.

Det har lige siden Sun Tzu været afgørende at have forudviden om fjenden i krigstid, men også i fredstid gør beslutningstagere klogt i rutinemæssigt at sikre sig indblik i omverdenens evner og hensigter. Imidlertid kan spionagen sjældent konkret forudsige, hvad der vil ske, så dens praktiske betydning er primært at begrænse uvisheden og komme med kvalificerede gæt på, hvad der vil ske, og hvad der næppe vil ske. Sådan arbejder fx Forsvarets Efterretningstjeneste (FE) i dens risikovurderinger, der gradbøjer sandsynligheden i procenter.

Reelt handler spionage/efterretningsvirksomhed om en treklang af indhentning af information, analyse af den indhentede information og så kontraspionage, som følgelig også kan forstås som en art kildekritik vel vidende, at omverdenen meget gerne vil føre beslutningstagere på vildspor.

Et af bogens kostelige eksempler på vildledning som gengældelse er Farewell Dossier. Den franske præsident Mitterand havde via en sovjetisk afhopper fået efterretninger om KGB's Line $\mathrm{X}$ industrispionage mod USA og lod sin viden tilgå USA's præsident Reagan i juli 1981.

I stedet for at afsløre Line $\mathrm{X}$ lod han CIA fodre KGB med mikrochips, der havde trojanske heste indprogrammeret. I en rum tid kørte de driftsikkert på $\mathrm{fx}$ de nye transsibiriske gasledninger, men så sprang svejsningerne og alt eksploderede i en ildstorm, der kunne ses fra rummet.

$\mathrm{Nu}$ kunne man tro, at der herefter kun var ondt blod mellem KGB og CIA, men nej, for i samme åndedrag omtaler bogen the Gavrilov channel, den særlige hotline, som de to rivaliserende efterretningstjenester oprettede $\mathrm{i}$ 1983, åbenbart fordi KGB stolede mere på Langleysegmentet end det formelle beslutningstagersegment i USA og derhjemme.

I det hele taget skal man indstille sig på, at en del guldkorn om Sovjetunionen/Rusland og Kina findes rundt omkring i bogen og ikke nødvendigvis i kapitlerne om disse to notoriske spionagestormagter. Her er det en kolossal hjælp, at udgiverne - forhenværende amerikanske efterretningsfolk - har gjort værket elektronisk tilgængeligt på AFIO's hjemmeside, så man kan navigere i det med søgeord.

\section{Spionagens rolle}

Denne anmelder holder meget af verdenshistorie og vil derfor anbefale den historiske del. Før den bringer bogen imidlertid en nok så velgørende oversigt (s. 16) over de mange episoder, hvor spionage påvirkede udfaldet såsom Zimmermanntelegrammet, 
der fik USA ind i Første Verdenskrig; 1973-kuppet i Chile og Irakkrigen i 2003, hvor høgene vred armen om på CIA, der så forlod sig på irakeren Curveballs fupevidens for Saddams masseødelæggelsesvåben - en skæbnesvanger fadæse.

I manges øjne var CIA's 'covert action' op til valget i Italien i 1948 lige så skæbnesvanger, men her fremhæver bogen konteksten af endnu mere massiv sovjetisk støtte til Italiens kommunister. Sagt med andre ord giver denne fremstilling et anderledes nuanceret, nogle vil sige idylliserende billede af CIA end det, offentligheden typisk har. Så der er faktisk behov for et korrektiv - også fordi det vi ved om KGB's tilsvarende gøren og laden i genren aktivnye meroprijatija/aktive tiltag, stort set aldrig tages i betragtning.

Bogens styrke er de grundige faktuelle fodnoter med henvisninger $\mathrm{fx}$ til Tim Weiners enfoldige værk om CIA (A Legacy of Ashes), der nok vil fænge forudsætningsløse CIA-kritiske læsere, men som har fået drøje hug af fagpersoner som R. Gerald Hughes i faglitteraturen andetsteds.

Redaktøren Peter C. Oleson står bag det spændende kapitel om spionagens afgørende rolle i Anden Verdenskrig, som den ifølge historikerne Hinsley og Kahn forkortede med adskillige år; det reddede utallige liv på begge sider af fronten.

Ved krigsudbruddet var USA en ren novice på feltet spionage, følgelig var det epokegørende ved krigen endvidere det samarbejde om deling af følsomme militære efterretninger, der blev formaliseret mellem først USA og Storbritan- nien med BRUSA-aftalen i 1943, siden det såkaldte Five Eyes-samarbejde mellem de fem engelsktalende nationer på feltet SIGINT (dvs. signals intelligence, altså elektronisk indhentning fra satellitter, radarstationer o. lign.).

\section{Udveksling af efterretninger}

For det er jo den anden side af sandheden om spionagen som evidens for anarkiet og statsegoismen i international politik. Mellem nogle stater trives et historiskkulturelt og institutionelt baseret værdifællesskab, som får dem til at overvinde anarkiet og formalisere udveksling af efterretninger/intelligence sharing.

Bogens kapitel om emnet - Intelligence Liaison - er skrevet af den København-baserede brite Adam D. M. Svendsen, der fremhæver Storbritannien som historiens første spionagestormagt, der levede så højt på sine bånd til omverdenen, at landet vedblev at 'punch above its weight'.

Der er næppe alverden af efterretningsdeling mellem Kina og Rusland, men på side 411 slår bogen ned på Cubas rolle som spionagementor for Venezuela (der leverer olie til gengæld). Michael J. Sulicks kapitel om den kolde krig - spionagens episke guldalder jævnfør Søren Ulrik Thomsen - fremhæver nyere forskning, der reelt frikender CIA for at radikalisere Iran i 1953 gennem kuppet mod Mossadeq.

Sulick har kun foragt til overs for KGB's evne til at korrigere fejl, men han og hans medforfattere tillægger alligevel spionagen en fredsbevarende rolle som ramme for kontrol med kold- 
krigens altafgørende nedrustningsaftaler under den lange slutfase.

\section{Mesterspionerne}

Kapitlet 'Espionage Against America' forærer læseren et forbryderalbum over Philby og den nyere tids mesterspioner, der forvoldte umådelig skade på amerikanske interesser. Eksempelvis flådeofficeren John Walker, Aldridge Ames, Robert Hanssen og Edward Snowden.

Som Snowdens principal anføres her 'Russia/Unknown'; han hoppede jo af i Moskva i 2013. Han afslørede hemmeligheder om Five Eyes-samarbejdet og anses derudover af Fred Kaplan for reelt at have hjulpet Kina og Rusland på cyberfeltet.

I det meget respektfult skrevne kapitel 'British Intelligence' gøres det klart, at Storbritannien forbliver et foregangsland udi spionage, idet Government Communications Headquarters (GCHQ) i 2013 ..." was developing a full spectrum military cyber capability, including a strike capability"'” (s. 645).
Her bøjes det i neon, at spionage er mere end indhentning; den har en handlingsdimension med navne som covert action (CIA) eller (KGB) aktivnye meropriatija. Men som en dansk ekspert i Kinas cyberkunnen skriver, er det logisk netop som afskrækkelse mod cyberangreb at skilte med, at man selv har offensive cyberevner.

À propos Kina og cyber så fremgår det flere steder i bogen, at Kina begynder at overhale Rusland som spionagestormagt. Bogens kapitel om Kina er desværre lidt tamt; her opleves den korte fremstillingsform som hæmsko for læserens 'need to know'; den samme kritik vil jeg rette mod Rusland-kapitlet, der ellers har autoriteten Robert W. Pringle som forfatter.

Man leder forgæves efter et Israel-kapitel; til gengæld er der et nok så relevant kapitel om Iran. Hvorom alting er, skal dette referenceværk om spionage i det 21. årh. sørme varmt anbefales! 